\title{
БИОЛОГИЧЕСКИ АКТИВНЫЕ СОЕДИНЕНИЯ С НИЗКОЙ ТОКСИЧНОСТЬЮ НА ОСНОВЕ ФОСФОРСОДЕРЖАЩИХ ПРОСТРАНСТВЕННО-ЗАТРУДНЕННЫХ ФЕНОЛОВ
}

\author{
Э.М. Гибадуллина', Нгуен Тхи Тху,, А.М. Шакиров ${ }^{1,2}$, А.С. Сапунова', \\ А.Д. Волошина', А.Б. Выштакалюк', А.Р. Бурилов' \\ ${ }^{1}$ ИОФХ им.А.Е. Арбузова - обособленное структурное подразделение ФИЦ КазНЦ РАН, \\ 420088, Россия, РТ, г. Казань, ул. Академика Арбузова, д. 8. \\ 2ФГБОУ ВО «Казанский национальный исследовательский технологический университет», \\ 420015, Россия, РТ, г. Казань, ул. К. Маркса, 68.
}

DOI: 10.19163/MedChemRussia2021-2021-34

E-mail:elmirak@iopc.ru

Удобной платформой в синтезе новых производных пространственно-затрудненных фенолов является использование фосфорсодержащих 2,6-ди-третбутил-4-метилен-2,5-циклогексадиенонов и 3,5-ди-трет-бутил-4-гидроксибензилхлорфосфоната. Цель работы - синтез новых высокоэффективных полифункциональных производных пространственно-затрудненных фенолов, проявляющих широкийспектрбиологическойактивностиснизкойтоксичностью.Намибылиизучены реакции 3,5-ди-трет-бутил-4-гидрокси-бензилхлорфосфоната спервичными и вторичными аминами, фосфорилированныхметиленхинонов с 0-нуклеофилами (спирты различной природы), N-нуклеофилами (алифатические амины, ароматические

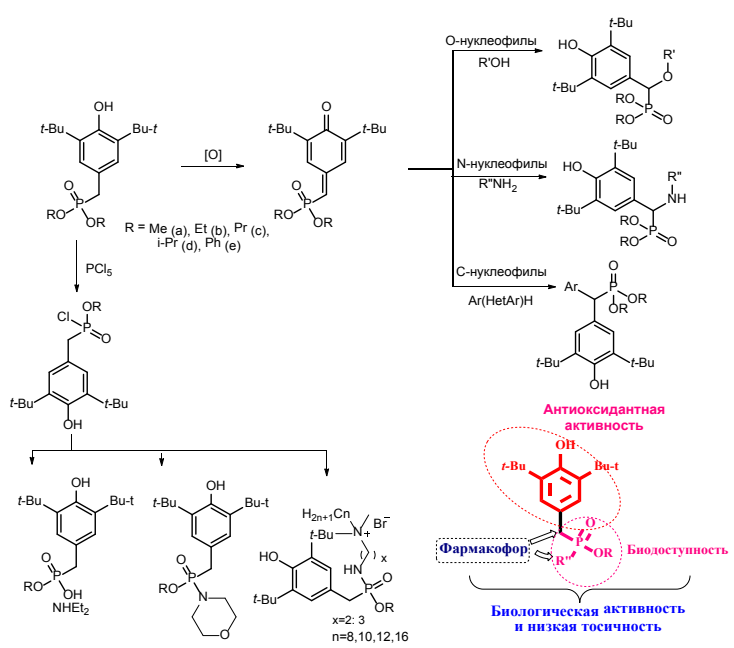
диамины, гетероциклические амины, гидразины), с С-нуклеофилами (фенольные производные, мета-фенилендиамин, 2,6-диаминопири-дин). Структура и состав синтезированных соединений установлены на основании данных ЯМР ${ }^{1} \mathrm{H},{ }^{13} \mathrm{C}$, ${ }^{31}$, ИК-спектроскопии, масс-спектрометрии (MALDI, ESI), элементного анализа. Изучена биологическая активность синтезированных соединений. В результате проведенных исследований обнаружены соединения,

обладающие антиоксидантной, антимикробной, туберкулостатической, противоопухолевой активностями с низкой токсичностью. 